\title{
Summer survival and habitat characteristics of a threespine stickleback (Gasterosteus aculeatus L.) Southern European population
}

\author{
Carlos M. Alexandre ${ }^{1, *}$ and Pedro R. Almeida ${ }^{1,2}$ \\ ${ }^{1}$ Institute of Oceanography, Faculty of Sciences University of Lisbon, Portugal, R. Ernesto de Vasconcelos, \\ Campo Grande, 1749-016 Lisboa, Portugal. \\ 2 Department of Biology, University of Evora, 7002-554 Évora, Portugal. \\ * Corresponding author: carlos.a.alexandre@clix.pt
}

Received: 2/9/08 Accepted: 7/1/09

\begin{abstract}
Summer survival and habitat characteristics of a threespine stickleback (Gasterosteus aculeatus L.) Southern european population

In April 2006, the relationships between the spatial distribution of a threespine stickleback (Gasterosteus aculeatus L.) southern European population during breeding season and the environmental parameters were investigated in the Almansor River, a Mediterranean type river in Portugal. This species distribution and survival rate during the previous summer period were also taken into account in this study. Despite the high mortality suffered by the juvenile in the upstream summer pools, the threespine stickleback adults continue to prefer this river stretch for spawning. In this period, male sticklebacks showed preference for sites that were rich in fish species and vegetation, where there is a greater protection against environmental fluctuations and anthropogenic pressures. Male distribution was also dependent on predation risk, for they were more abundant at sites with fewer potential predators. The abundance of females was positively related to male abundance, showing that, above all other variables, male nesting site was the main factor influencing their distribution, during breeding season.
\end{abstract}

Key words: Threespine stickleback, Mediterranean type streams, summer survival, breeding season, spatial distribution, Portugal.

\section{RESUMEN}

Supervivencia estival y caracteristicas del habitat de una población de espinoso (Gasterosteus aculeatus L.) del Sur de Europa

En abril de 2006 se estudiaron las relaciónes entre la distribución espacial de una población de espinosos del sur de Europa (Gasterosteus aculeatus L.) durante la época de reproducción y los parámetros ambientales en el río Almansor, un río de Portugal de tipo mediterráneo. La distribución de esta especie y la tasa de supervivencia durante el anterior período estival también se tuvieron muy en cuenta en este estudio. A pesar de la alta tasa de mortalidad de los juveniles en las charcas de verano aguas arriba, los espinosos adultos siguen prefiriendo este tramo del río para el desove. Durante este periodo, los machos de espinoso prefirieron lugares ricos en especies de peces y vegetación, donde están más protegidos de las fluctuaciones ambientales y la presión antropogénica. La distribución de los machos también dependía del riesgo de depredación, puesto que eran más abundantes en lugares con menos depredadores potenciales. La abundancia de hembras se relacionaba positivamente con la de los machos, poniendo de manifiesto que, por encima de todas las demás variables, el lugar en el que el macho construye el nido fue el principal factor de influencia en su distribución durante la época de reproducción.

Palabras clave: Espinoso, ríos de tipo mediterráneo, supervivencia en verano, época reproductiva, distribución espacial, Portugal. 


\section{INTRODUCTION}

The threespine stickleback (Gasterosteus aculeatus L.) comprises a complex of widely distributed and phenotypic differentiated populations, including some that are clearly separate biological species (Hagen, 1967; Rundle et al., 2000; Berna, 2001; Mattern, 2004). In the Iberian Peninsula, the taxonomic status of this species complex is not completely resolved. Some authors have registered several morphological and meristic differences between individuals from this southern region and others coming from more northern latitudes (Lobón-Cervia et al., 1988; Fernandez et al., 2000; Hermida et al., 2005). After a brief period, where this southern population was classified as Gasterosteus gymnurus (Cuvier, 1829), which was never completely accepted, the latest taxonomic review included it again in G. aculeatus (Kottelat \& Freyhof, 2007). This species usually includes two different ecological forms, namely an anadromous form that inhabits the coastal areas and migrates upstream into riverine environments during breeding season, and a freshwater resident form (Rogado et al., 2005). These two forms have phenotypic differences; the number of lateral bony plates, size and body coloration being the most visible (Snyder, 1991; Rubidge, 2000; Berna, 2001).

The reproduction of G. aculeatus usually occurs between April and June, when the water temperature is close to $14-16^{\circ} \mathrm{C}$ (Sterba, 1973; Allen and Wootton, 1982; Doadrio, 2001). In anadromous populations, the upstream migration begins in early spring. At this time, males develop secondary sexual characteristics such as conspicuous breeding colours with a red throat and abdomen and bright blue eyes (Páll et al., 2005). Females become sexually mature only once per year but the spawning occurs at intervals of a few days (Fletcher and Wootton, 1995). When the breeding season begins, the male becomes territorial and aggressive towards other fishes and selects a place to build the nest to where the females are attracted and where they deposit their eggs (Peultkuri et al., 1995).

When this species is present in freshwater environments, it occurs in many habitats, but is less common or even absent in mountain and intermittent hydrological regime streams (Liythgoe and Liythgoe, 1971; Garcia-Berthou and Moreno-Amich, 2000; Doadrio, 2001; Rogado et al., 2005). There is a variety of biotic and abiotic parameters, which influence habitat selection by this species. Some of these parameters have been described, namely the sediment characteristics (e.g. Mori, 1994; Rodewald and Foster, 1998; Webster and Hart, 2004), dissolved oxygen (Lewis et al., 1972), current velocity and depth (e.g. Almaça, 1996; Copp and Kovac, 2003), and presence or absence of vegetation (e.g. Almaça, 1996; Doadrio, 2001; Candolin and Voigt, 2003).

Observations made previous to this study, confirmed the presence of an important threespine stickleback population in the Almansor River, a Mediterranean type stream, known for having a marked intermittent hydrological regime. The lack of knowledge about the ecology of this species in Portugal, close to the southern margin of its distribution, and the fact that it was classified as "endangered" in the last revision of the Portuguese Red List of Endangered Species (Rogado et al., 2005), makes the gathering of information in order to propose management measures that could avoid the extinction of this species from this region imperative. Having this in mind, two main objectives were defined in this study: (i) to characterize the species' spatial distribution and survival during the summer period in an intermittent river, and (ii) to identify the relationship between environmental parameters and the spatial distribution of the adult fraction of the population during the breeding season.

This study is of great importance, because the identification of preferential aggregation sites of individuals of this species during these two critical periods of their life cycle, would allow a proper management of the most important sites for the conservation of the threespine stickleback in Portugal.

\section{MATERIAL AND METHODS}

\section{Study area}

One of the major tributaries of the Sorraia River, the Almansor River, covers an area of about 


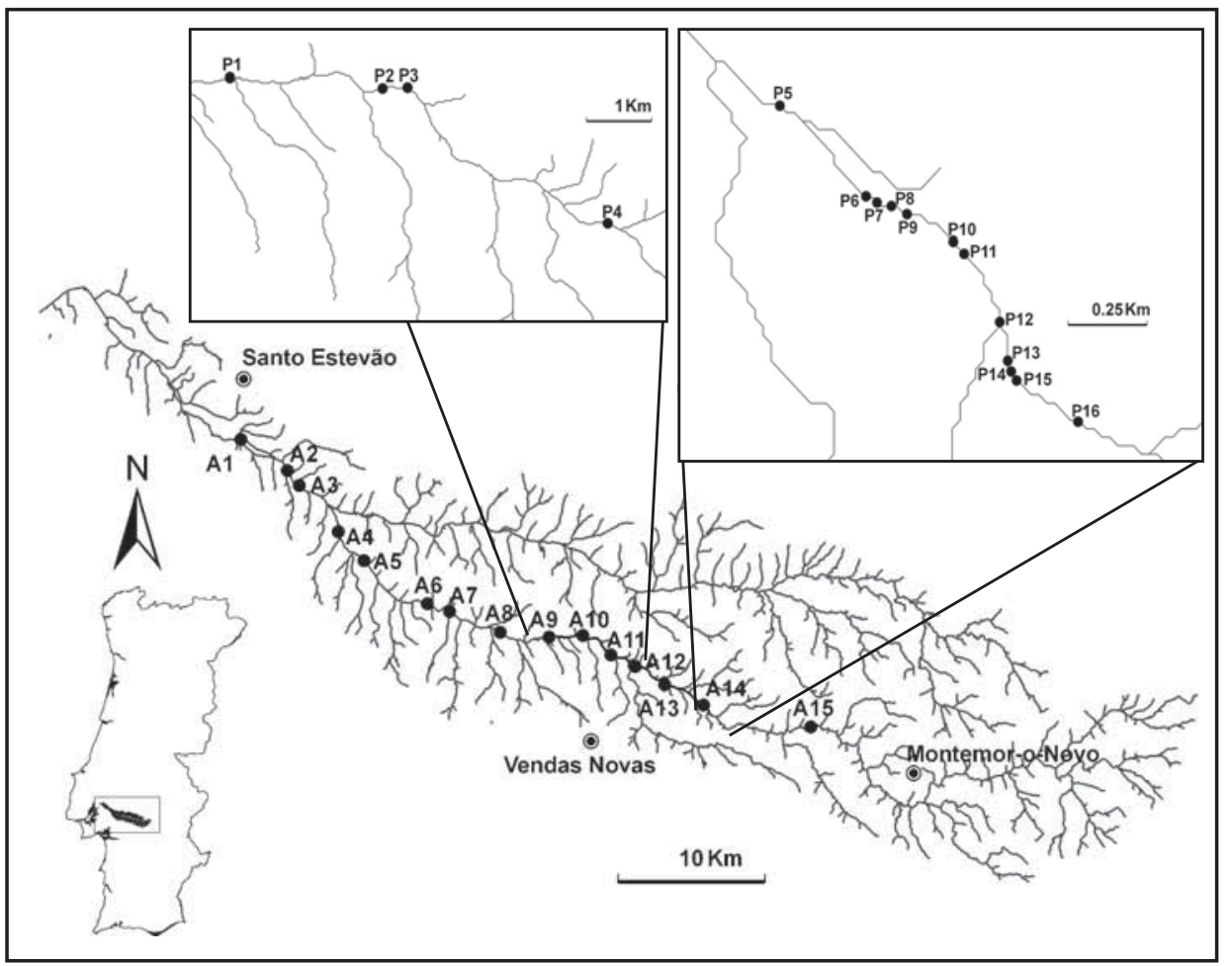

Figure 1. Location of the study area in the Almansor River, Portugal. Circles $(\bullet)$ indicate the position of the sites (A1-A15) sampled in April 2006. The amplified pictures represent the location of the 16 isolated pools (P1-P16) sampled in August and October 2005. Localización del área de estudio en el río Almansor. Portugal. Los puntos (•) indican la posición de los lugares (A1-A15) muestreados en abril de 2006. Las imágenes ampliadas representan la localización de las 16 charcas aisladas (P1-P16) muestreadas en agosto y octubre de 2005.

$1081 \mathrm{~km}^{2}$, with a length of $96.7 \mathrm{~km}$. These two rivers belong to the Tagus River basin, considered Europe's fifth major basin in terms of area and the third on the Iberian Peninsula, covering a total surface of about $80629 \mathrm{~km}^{2}$, of which $24800 \mathrm{~km}^{2}$ $(30 \%)$ are in Portuguese territory (INAG, 1999). The Almansor River is located in the southern region of Portugal in an area characterized by low mean annual precipitation $(730 \mathrm{~mm})$ and high mean annual temperature $\left(16^{\circ} \mathrm{C}\right)$, having a typical Mediterranean flow regime. During summer, it is usual to see a completely dry bed or the formation of isolated pools in some reaches of the river. This river is subject to considerable stress, especially of anthropogenic origin, mainly because of the many towns with small industries and agricultural fields through which its course runs.

The sampling areas were selected following previous surveys (July 2005 and March 2006), which identified a reach with 16 isolated pools for the summer samplings and 15 sites to be sampled in the following spring (Fig. 1).

\section{Field Sampling}

For the characterization of this species' distribution and survival during the summer period, the 16 isolated pools selected were sampled for the first time in August 2005. Fish were collected with an electric fishing device (Hans Grassl EL62, 600V DC, 10A). All fishing samples took a minimum time of 20 minutes for later calculation of the capture per unit effort (CPUE). All animals caught at each sampling site were counted and the total length (TL) of threespine sticklebacks was measured to the nearest millimetre. At the end of each sampling session, all animals were returned alive to the pools. Later, by 
the end of the summer period in October, the remaining pools that did not dry were re-sampled for fish survival estimation.

In April 2006, with the river in its regular flow, samples were collected at 15 sampling sites, following the procedure previously applied in the summer. During the sampling, all species found were collected, including the crustacean Procambarus clarkii (Girard, 1852), commonly known as the red swamp crayfish and described by some authors as a serious threat to threespine stickleback eggs (Doadrio, 2001; Foster et al., 2003; Rogado et al., 2005).

The number of lateral plates from both sides and the body coloration of each individual were recorded on both sampling seasons, in order to distinguish between the two ecological forms of this species.

For each one of the 15 sites sampled in April 2006, dissolved oxygen $\left(\mathrm{mg} \mathrm{L}^{-1}\right)(O x y)$, conductivity $(\mu \mathrm{S} / \mathrm{cm})($ Cond), and $\mathrm{pH}$ (Sorensen scale) $(\mathrm{pH})$ were recorded, using a calibrated multi parameter probe (YSI 600 XLM-M) coupled to a data logger viewer (YSI $650 \mathrm{MDS}$ ) and a $\mathrm{pH}$ probe ( $p H 197 \mathrm{WTW})$. The temperature $\left({ }^{\circ} \mathrm{C}\right)$ was also recorded using a data logger Vemco Minilog$t$ during a $24 \mathrm{~h}$ period, programmed with a time interval of 15 minutes between two consecutive readings. Current velocity $\left(\mathrm{ms}^{-1}\right)$ (Vel) was measured using a Valeport current meter (Model 105) and the mean depth (Dpt) was obtained by taking measurements (precision of $0.01 \mathrm{~m}$ ) several times at each sampling site. To determine the granulometrical composition and the organic matter content $(O M C)$ of the river bed sediment, the first $15 \mathrm{~cm}$ of sediment were collected using a UWITEC corer (inner diameter: $9 \mathrm{~cm}$ ), in each of the sampling sites. Finally, for each site sampled, shade (Shd) (provided by the riparian habitat) and aquatic vegetation cover ( $V C o v$ ) percentages were registered by direct observation. The classes used to measure these two parameters were: $0-20 \%$; 20-40\%; 40-60\%; 60-80\%; 80-100\%.

\section{Laboratory Analysis}

The granulometrical composition was determined following the procedure described by Almeida and Quintella (2002). The sediment samples were dried at $60{ }^{\circ} \mathrm{C}$ during $24 \mathrm{~h}$ and a $100 \mathrm{~g}$ sub-sample (dry weight) was washed in a $0.063 \mathrm{~mm}$ sieve to determine the finer fraction (silt). The sediment retained by the sieve (sand and gravel) was dried again at $60{ }^{\circ} \mathrm{C}$ for another $24 \mathrm{~h}$ and passed through a five sieve AFNOR type column $(9.5 \mathrm{~mm}$, $2.0 \mathrm{~mm}, 0.5 \mathrm{~mm}, 0.25 \mathrm{~mm}$ and $0.063 \mathrm{~mm}$ ). The sediment fractions retained in each sieve were then individually weighed. The sampling sites were then classified according to the Roux scale as gravel $(>2.0 \mathrm{~mm})$, sand $(2.0 \mathrm{~mm}-0.063 \mathrm{~mm})$ and silt $(<0.063 \mathrm{~mm})$ (Roux, 1964).

The OMC ( \%) was estimated from the reduction in weight of a $50 \mathrm{~g}$ portion of sediment, after ignition at $500{ }^{\circ} \mathrm{C}$ during a $24 \mathrm{~h}$ period (Almeida et al., 1993).

\section{Data Analysis}

The abundance of $G$. aculeatus individuals in each sampling station in Almansor River, for each sex and length-class was estimated from CPUE (capture per unit effort expressed in number of individuals caught per 20 minutes of fishing). After being measured, these individuals were assigned to $2 \mathrm{~mm}$ length-classes. Fish species-richness (SRch) and species diversity (Shannon-Wiener Index; SDiv), without considering the sticklebacks, were determined for each sampling site. The abundance (CPUE) of potential predators (Pred) of threespine stickleback and its eggs was calculated, using the number of specimens of mosquito fish Gambusia holbrooki Girard, 1859, pumpkinseed sunfish Lepomis gibbosus L., eel Anguilla anguilla L., and red swamp crayfish $P$. clarkii.

Before the statistical analysis, all non normal variables (Shapiro-Wilk $W$-test, $P<0.05$ ) were log-transformed to reduce deviations from this assumption.

An ascending stepwise multiple linear regression method was used in order to relate the environmental parameters recorded in each site sampled in April with the threespine stickleback spatial distribution, quantified as the species abundance. In the first two analyses, male $(M A b)$ and female $(F A b)$ abundances were used alternately as dependent and independent variables. A third regression procedure was applied, this time re- 
Table 1. CPUE (number of individuals caught per 20 minutes) of the species G. aculeatus in each sampled pool in the Almansor River and the corresponding survival rate. CPUE (número de individuos capturados cada 20 minutos) de la especie G. aculeatus en cada charca muestreada del río Almansor y tasa de supervivencia correspondiente.

\begin{tabular}{cccc}
\hline Sampled pools & CPUE (August 2005) & CPUE (October 2005) & Survival rate (\%) \\
\hline P1 & 8.8 & Pool dried & - \\
P2 & 0.0 & 0.0 & - \\
P3 & 18.0 & 9.0 & 50.8 \\
P4 & 2.0 & 1.0 & - \\
P5 & 0.0 & 0.0 & - \\
P6 & 62.0 & Pool dried & - \\
P7 & 5.0 & Pool dried & - \\
P8 & 4.0 & Pool dried & - \\
P9 & 179.0 & Pool dried & - \\
P10 & 80.0 & Pool dried & - \\
P11 & 7.3 & Pool dried & - \\
P12 & Pool dried & - \\
P13 & 15.0 & Pool dried & - \\
P14 & 66.4 & Pool dried & 28.5 \\
P15 & 33.6 & Pool dried & \\
P16 & 1.0 & 1.0 & \\
\hline
\end{tabular}

moving male abundance from the list of independent variables, maintaining female abundance as the dependent variable. The abundance of the two genders was analysed separately to verify if there were any sex related differences in the way the environmental parameters are related to this species' distribution during the breeding season.

Before this analysis, the relation between all independent variables was tested using a Pearson's correlation test. From the variables that exhibited a strong significant correlation $(r \geq 0.90$; $P$-value $<0.05)$, only one of them was used in the multiple regression procedures to avoid redundancy errors. All statistical procedures were applied using the SPSS 12.0 package.

\section{RESULTS}

During the first sampling period, in August 2005, 537 threespine sticklebacks were caught, in almost all of the 16 pools, with the exception of $\mathrm{P} 2$ and P5 where no other fish species was captured either. The highest CPUE value of 179.0 was observed in pool P9 where the number of sticklebacks caught represented $33 \%$ of the total number of this species individuals registered in the first sampling season. In the second sampling period, by the end of the summer, only five pools remained (P2, P3,
P4, P5 e P16) since all the other had completely dried out, causing a drastic reduction in almost all fish species, including the sticklebacks (Table 1). A total of only 17 sticklebacks were caught, at pools $\mathrm{P} 3$, P4, and P16, resulting in a low global survival rate of $3.2 \%$. The highest abundance value during the October samplings was observed at pool P3 with a CPUE value of 9.0, representing $82 \%$ of the total number of threespine sticklebacks caught at the end of the summer, but only $2 \%$ of all the individuals caught during the two pool sampling campaigns. Individually, for each one of the remaining pools, the species' survival rate presented medium values, with a maximum of $51.8 \%$ at pool P3. The other fish species sampled at the summer pools exhibited different survival rates. We can only consider pools P3 and P16, where the number of species captured and their abundance on both sampling periods was enough to compare with the sticklebacks (in P4 the only fish caught were two sticklebacks). The individuals of the Genera Lampetra spp. presented low survival rates (40\% and $5 \%$ at pool P3 and P16, respectively). Species like Pseudochondrostoma polylepis Steindachner, 1864, Pseudochondrostoma lusitanicum CollaresPereira, 1980, and L. gibbosus exhibited generally high mortality in the remaining pools, resulting in survival rates near $0 \%$, while more resistant taxa like G. holbrooki, A. anguilla, Iberocypris 


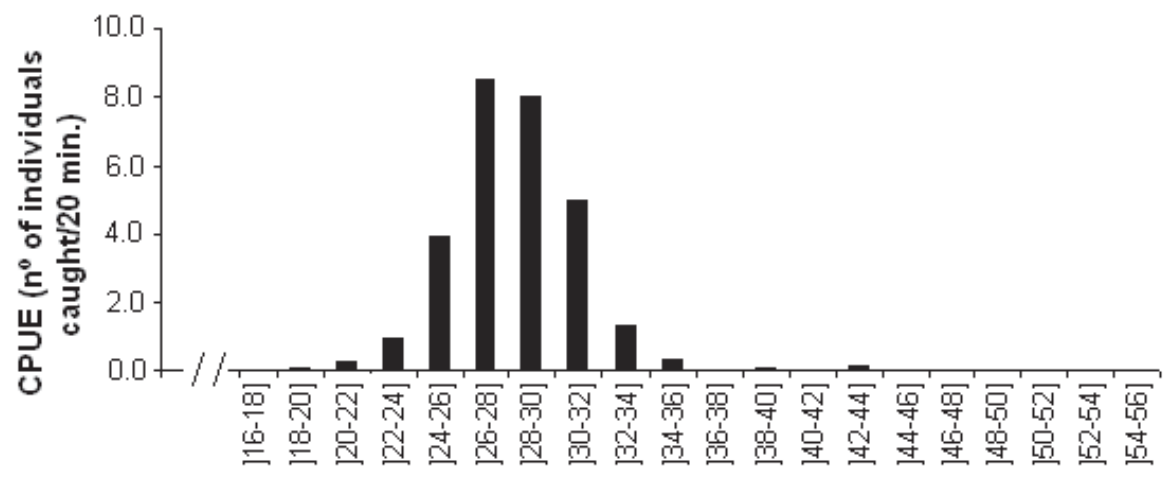

Total lenght $(\mathrm{mm})$

Figure 2. Length-frequency distribution of the threespine sticklebacks caught in August and October of 2005 in the sampled pools in the Almansor River $(n=554)$. Distribución de frecuencia de tallas de los espinosos capturados en agosto y octubre de 2005 en las charcas muestreadas en el río Almansor $(\mathrm{n}=554)$.

alburnoides Steindachner, 1866, and Luciobarbus bocagei Steindachner, 1864 showed almost no reduction in the number of fish at P3 and P6, exhibiting survival rates near $100 \%$.

The individuals caught in the sampled summer pools had a minimum total length (TL) of $20 \mathrm{~mm}$ and a maximum TL of $43 \mathrm{~mm}$. The mean TL was $28.7 \pm 2.9 \mathrm{~mm}$ (mean \pm s.d.). The length-frequency distribution for these specimens (Fig. 2) has only one peak, probably associated to the respective age-class. All the individuals presented a reduced number of lateral plates (maximum of 1 or 2 per side) and greenish body coloration. The same characteristics were

Table 2. Abiotic characteristics of the water-sediment interface, aquatic community structure and shade of the area studied in April 2006, in the Almansor River. Características abióticas de la interfase agua-sedimento, estructura de la comunidad acuática y sombra del área estudiada en abril de 2006 en el río Almansor.

\begin{tabular}{|c|c|c|c|c|c|c|c|c|c|c|c|c|c|c|}
\hline & \multicolumn{8}{|c|}{ Abiotic parameters } & \multicolumn{6}{|c|}{ Biotic parameters } \\
\hline & $\begin{array}{l}\text { Dissolved } \\
\text { oxygen } \\
\left(\mathrm{mgL}^{-1}\right)\end{array}$ & $\begin{array}{c}\text { Conductivity } \\
(\mu \mathrm{S} / \mathrm{cm})\end{array}$ & $\mathrm{pH}$ & $\begin{array}{c}\text { Maximum } \\
\text { temperature } \\
\left({ }^{\circ} \mathrm{C}\right)\end{array}$ & $\begin{array}{l}\text { Minimum } \\
\text { temperature } \\
\left({ }^{\circ} \mathrm{C}\right)\end{array}$ & $\begin{array}{c}\text { Thermal } \\
\text { amplitude } \\
\left({ }^{\circ} \mathrm{C}\right)\end{array}$ & $\begin{array}{l}\text { Current } \\
\text { velocity } \\
\left(\mathrm{ms}^{-1}\right)\end{array}$ & $\begin{array}{l}\text { Depth } \\
(\mathrm{m})\end{array}$ & $\begin{array}{l}\text { OMC } \\
(\%)\end{array}$ & $\begin{array}{l}\text { Species } \\
\text { richness } \\
\left(\mathrm{n}^{\circ} \text { taxa }\right)\end{array}$ & $\begin{array}{c}\text { Species } \\
\text { diversity }(\mathrm{H})\end{array}$ & $\begin{array}{c}\text { Potential } \\
\text { predators } \\
(\mathrm{CPUE})\end{array}$ & $\begin{array}{c}\text { Aquatic } \\
\text { vegetation } \\
\text { cover (\%) }\end{array}$ & $\begin{array}{c}\text { Shade } \\
(\%)\end{array}$ \\
\hline A1 & 8.51 & 480 & 7.32 & 18.4 & 16.3 & 2.1 & 0.39 & 0.26 & 2.8 & 2 & 0.295 & 37.8 & 90.0 & 10.0 \\
\hline $\mathrm{A} 2$ & 8.46 & 487 & 7.36 & 19.2 & 15.1 & 4.1 & 0.29 & 0.20 & 0.6 & 3 & 0.409 & 21.8 & 70.0 & 10.0 \\
\hline A3 & 8.30 & 488 & 7.31 & 19.9 & 14.8 & 5.1 & 0.16 & 0.26 & 2.8 & 5 & 1.312 & 14.8 & 30.0 & 30.0 \\
\hline A4 & 8.54 & 505 & 7.52 & 19.5 & 14.2 & 5.3 & 0.39 & 0.31 & 0.8 & 5 & 1.395 & 8.4 & 10.0 & 50.0 \\
\hline A5 & 9.46 & 483 & 7.65 & 20.3 & 14.0 & 6.3 & 0.42 & 0.32 & 0.3 & 4 & 0.870 & 20.4 & 10.0 & 70.0 \\
\hline A6 & 8.44 & 514 & 7.60 & 20.8 & 13.8 & 7.0 & 0.26 & 0.63 & 0.3 & 8 & 0.724 & 13.0 & 70.0 & 70.0 \\
\hline A7 & 9.27 & 488 & 7.51 & 20.5 & 13.3 & 7.2 & 0.36 & 0.23 & 0.3 & 3 & 0.639 & 1.8 & 30.0 & 70.0 \\
\hline A8 & 8.71 & 475 & 7.45 & 17.1 & 15.1 & 2.0 & 0.43 & 0.29 & 0.6 & 8 & 0.817 & 6.8 & 90.0 & 10.0 \\
\hline A9 & 9.78 & 511 & 7.46 & 16.9 & 15.2 & 1.7 & 0.24 & 0.33 & 1.6 & 7 & 1.630 & 35.7 & 90.0 & 10.0 \\
\hline A10 & 8.52 & 513 & 7.57 & 15.9 & 13.9 & 2.0 & 0.24 & 0.34 & 0.5 & 5 & 0.718 & 3.7 & 90.0 & 30.0 \\
\hline A11 & 8.52 & 534 & 7.54 & 16.2 & 13.6 & 2.6 & 0.46 & 0.31 & 1.3 & 5 & 1.053 & 8.3 & 90.0 & 10.0 \\
\hline A12 & 8.67 & 554 & 7.58 & 16.8 & 13.2 & 3.6 & 0.19 & 0.33 & 0.6 & 7 & 1.083 & 9.3 & 90.0 & 30.0 \\
\hline A13 & 8.98 & 529 & 7.65 & 17.7 & 14.3 & 3.4 & 0.36 & 0.33 & 0.7 & 5 & 1.250 & 31.7 & 70.0 & 10.0 \\
\hline A14 & 9.40 & 488 & 7.89 & 16.6 & 14.6 & 2.0 & 0.33 & 0.62 & 0.8 & 6 & 1.677 & 4.9 & 50.0 & 90.0 \\
\hline A15 & 6.77 & 511 & 7.44 & 16.8 & 15.1 & 1.7 & 0.04 & 0.72 & 0.6 & 2 & 0.234 & 8.8 & 30.0 & 50.0 \\
\hline Mean & 8.68 & 504 & 7.50 & 18.2 & 14.4 & 3.7 & 0.30 & 0.37 & 1.0 & 5 & 0.940 & 15.1 & 60.7 & 36.7 \\
\hline S.D. & 0.69 & 22.7 & 0.10 & 1.7 & 0.8 & 2.0 & 0.15 & 0.16 & 0.8 & 2 & 0.450 & 11.8 & 31.0 & 27.9 \\
\hline Min. & 6.77 & 475 & 7.30 & 15.9 & 13.2 & 1.7 & 0.04 & 0.20 & 0.3 & 2 & 0.230 & 1.8 & 90.0 & 10.0 \\
\hline Max. & 9.78 & 554 & 7.90 & 20.8 & 16.3 & 7.2 & 0.46 & 0.72 & 2.8 & 8 & 1.670 & 37.8 & 10.0 & 90.0 \\
\hline
\end{tabular}

S.D. - Standard Deviation; OMC - Organic Matter Content 


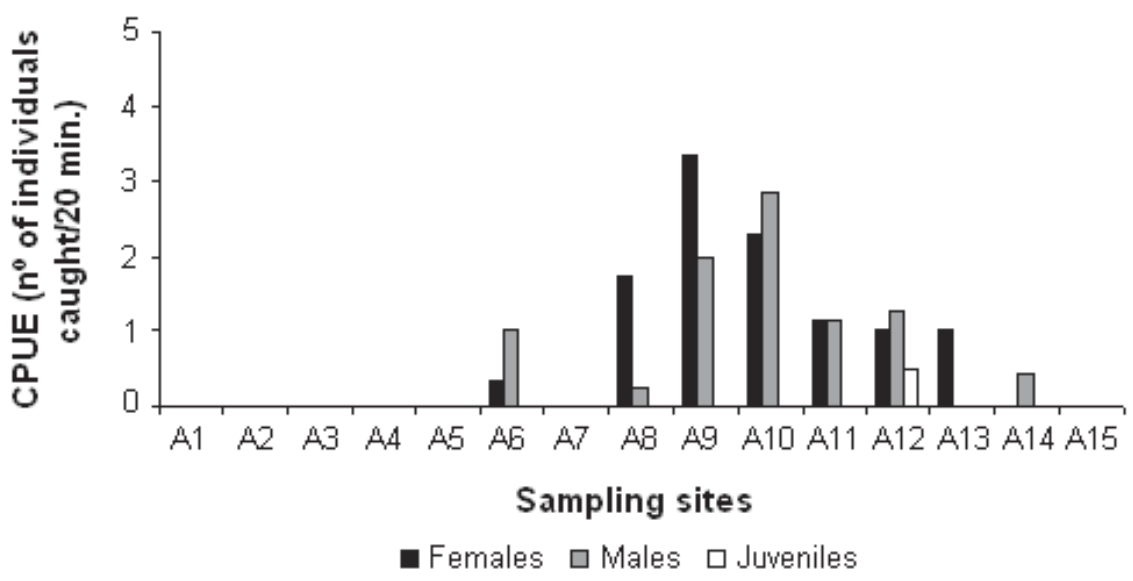

Figure 3. Distribution of the individuals of the species G. aculeatus caught in April $2006(n=69)$ in the sampled sites in the Almansor River. Distribución de los individuos de la especie G. aculeatus capturados en abril de $2006(\mathrm{n}=69)$ en los sitios muestreados en el río Almansor.

observed in the sticklebacks caught in the next spring samplings, indicating that they all belong to the freshwater resident population.

In the April 2006 samplings, 69 threespine sticklebacks were caught, of which 30 were males, 37 females and two individuals that due to their small size were both identified as juveniles. These animals were caught in the river stretch, between the sampling sites A6 and A14, with the exception of site A7. The highest CPUE values were observed at sampling sites A9 and A10, where the number of threespine sticklebacks represented nearly $50 \%$ of the total number of these specimens caught during the spring field campaign (Fig. 3).
The individuals caught in April had a minimum TL of $17 \mathrm{~mm}$ (juvenile) and a maximum TL of $55 \mathrm{~mm}$. The mean TL was $45.5 \pm 5.7 \mathrm{~mm}$. The length-frequency distribution (Fig. 4) has three distribution peaks that are probably associated to each age-class of this population. Two individuals of smaller length-classes were also caught, probably belonging to the 2006 recruitment season. The larger length-classes (from $46 \mathrm{~mm}$ to $56 \mathrm{~mm}$ ) were mostly represented by females, while males were dominant in the smaller classes.

In the spring, throughout the sampling area, the dissolved oxygen exhibited some discrepancy among the sampled sites, with $3.0 \mathrm{mg} \mathrm{L}^{-1}$ of dif-

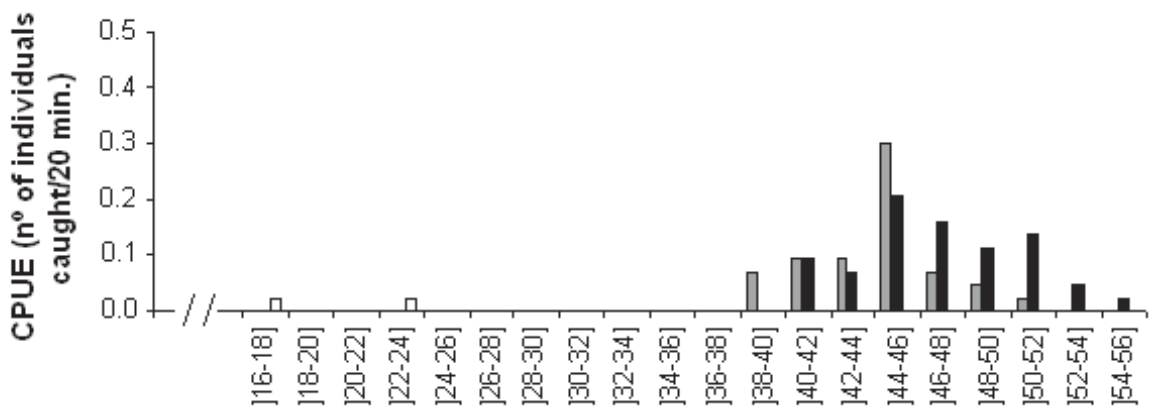

Total lenght $(\mathrm{mm})$

- Females $\square$ Males $\square$ Juveniles

Figure 4. Length-frequency distribution of the threespine sticklebacks caught in April 2006 in the sampled area $(n=69)$. Distribución de frecuencias de tallas de los espinosos capturados en abril de 2006 en el área de muestreo $(\mathrm{n}=69)$. 
ference between the extreme values (Table 2). Conductivity and $\mathrm{pH}$ showed little variation along the sampling sites. For temperature, the maximum (TMax) and minimum (TMin) values recorded along a $24 \mathrm{~h}$ cycle and thermal amplitude (TAmp) were calculated for each sampling site and subsequently used as independent variables in the statistical analyses. Maximum temperature exhibited little variation along the sampling area $(18.0 \mathrm{C} \pm 1.7$; mean \pm s.d.). The sites that presented lower maximum temperatures, also exhibited smaller thermal amplitudes. Between A7 and A8, a sudden decrease of thermal amplitude was recorded, possibly associated with the existence, starting from this point, of a denser riparian habitat, which confers a higher protection against environmental fluctuations to the upstream reaches of the river. While the mean depth had a relatively constant value throughout the sampling area, the current velocity showed great variation along the sampling sites in the Almansor River $(0.30 \pm 0.15$, mean \pm s.d.). The substrate at the sampling sites was generally low in organic matter (OMC) and essentially distributed between two sediment classes, sand and gravel-sand $(80 \%)$.

The fish species-richness and diversity showed great variation between the sampled sites. The lowest values to these parameters were obtained at A15, reflecting the reduced number of species caught at this site and the dominance of one of them (Table 2). Like these two parameters, the abundance of potential predators also exhibited differences between the sampling sites. At A1, this variable attained its maximum value, where the individuals considered as being potential predators represented nearly $95 \%$ of the total number of fishes and crayfish caught.

The great majority of the sites sampled in April 2006 presented low values of shade, which is probably related to the almost total absence of riparian vegetation observed in the downstream reaches of this river. In contrast, these sites generally exhibited high values of aquatic vegetation cover, with the maximum value of $90 \%$ being observed at six of the 15 sampled sites.

Before the application of the three multiple regression analyses, the application of Pearson's correlation test showed that the variable "thermal amplitude" exhibited a strong relationship with maximum temperature $(r=0.94 ; P<0.001)$. Thereby, only the thermal amplitude variable was used in the subsequent statistical analysis. The other variables used in the regression analyses were the ones described in Table 2.

In the first multiple regression, where the abundance of males was used as the dependent variable and the abundance of females as one of the independent variables, the variables related with male abundance were the fish speciesrichness, the aquatic vegetation cover and the abundance of potential predators. The speciesrichness and the aquatic vegetation cover were positively correlated with male abundance, indicating that males were more abundant at sites with high number of species and greater aquatic vegetation cover. The sites with a lower abundance of potential predators presented a higher abundance of males. All variables were significant $(P<0.05)$ and none of them showed co-linearity problems (VIF $<10)$. The model was highly significant $\left(r^{2}=0.788 ; F=18.319\right.$; $d f=14 ; P<0.001)$ with an estimated linear equation of $y=0.138+0.146$ SRch $+0.009 \mathrm{VCov}-$ 0.197 Pred (not standardized coefficients).

In the second multiple regression, where female abundance was used as the dependent variable and including male abundance as one of the independent variables, the only variable that entered in the model was the male abundance, implying that females were more abundant at sites with higher male abundance. This variable was significant $(P<0.05)$ and did not showed co-linearity problems $(V I F<10)$. The model was also significant $\left(r^{2}=0.528 ; F=16.647\right.$; $d f=14 ; P<0.05)$ resulting in an estimated linear equation of $y=0.119+0.759 M A b$.

In the third and last multiple regression, male abundance was removed from the list of independent variables and female abundance was still used as the dependent variable. Thus, the variables related with the abundance of threespine female were the species-richness, the aquatic vegetation cover and conductivity. All variables were positively and significantly $(P<0.05)$ related to female abundance and none of them presented co-linearity problems $(V I F<10)$. The model 
was highly significant $\left(r^{2}=0.804 ; F=20.008\right.$; $d f=14 ; P<0.001$ ), exhibiting an estimated linear equation of $y=-4.348+0.008 \mathrm{VCov}+$ 0.114 SRch + 7.472 Cond.

\section{DISCUSSION}

In rivers with Mediterranean characteristics, such as the Almansor River, pool availability as summer refuge for the fish fauna is not only determined by its water availability but also by the environmental parameters variations generally associated to this type of ecosystem (Moyle and Vondracek, 1985; Gasith and Resh, 1999; Magoulick, 2000; Schwartz and Jenkins, 2000; Ostrand \& Wilde, 2004). The threespine stickleback inadaptability to these streams, described by Rogado et al. (2005), is well documented in the present study where, despite the species high abundance in the first sampling campaign, the survival rate by the end of the summer period was low. Though the main cause of this severe mortality was the decrease of water availability, this species survival in each one of the remaining pools followed the same reduction pattern, which is probably related to the environmental degradation that usually occurs during the drought, particularly the temperature rise and dissolved oxygen depletion, as it is described for other fish species (Mundahl, 1990, Soncini and Glass, 1997; Elliott, 2000; Magoulick, 2000). When comparing this species survival rates with the ones from the other sampled taxa we observed that the sticklebacks exhibited lower survival rates than the more tolerant specimens (i.e. eel, mosquitofish, etc.) but higher than the values obtained by lampreys and nases, who are less adapted to the environmental constraints generally associated to the drought period (Ilhéu, 2004). Comparing it with the historical data set, in the year 2005 the study area presented an expected mean annual temperature of $16.3{ }^{\circ} \mathrm{C}$, but a much lower annual precipitation value of $343 \mathrm{~mm}$. August was a particularly dry month, which probably worsened the degradation of the summer pools environmental conditions, contributing to the species survival rate decrease. To clarify these results, a new study contemplating a comprehensive characterization of the sampled pools and more extended in time and space, would provide valuable information about the species response to this environmental fluctuations.

Based on this species length-growth relation (Jones and Hynes, 1950), according to which a 1-year individual generally has $35-40 \mathrm{~mm}$, the length distribution of the specimens caught at the sampled pools lead us to conclude that this part of the population was mainly composed of juveniles, probably from the same year's recruitment. The almost complete absence of adults from the area sampled during the summer period might represent a strategy to avoid the drought effects by migrating to downstream reaches of the river were the water availability is higher even in the summer, a behaviour commonly observed in other freshwater fish species from these regions (Matthews, 1998). This hypothesis is supported by the capture, during this season, of threespine sticklebacks from higher length-classes in lotic reaches immediately downstream from the sampling area.

Despite the environmental constraint and high mortality suffered by the juvenile fraction of this population during the drought, in the upstream reaches of Almansor River, when the breeding season begins the stickleback adults continue to prefer this area, since in April samplings, the great majority of this species individuals were caught upstream in the river, near to the sampled pools area. In fact, the higher abundances during the spring samplings were observed in the river stretch that corresponds to the pools that never dried out completely.

This study did not confirm the presence of the two ecological forms of G. aculeatus in the Almansor River, since only the freshwater resident form was caught in both sampling seasons. Considering the fact that there isn't any obstacle preventing the migratory fish specimens of reaching the study area, the absence of this species in the sampled downstream reaches may imply that the anadromous form is absent in this river. According to Rubidge (2000), in spite of the distribution overlap exhibited by the two forms during the breeding season, the anadromous form is more common in the downstream reaches. Future genetic and morphometric studies, defining the differences between the two forms of this species, 
assume importance for confirming the presence of the anadromous form in Portugal.

In the 2006 spring samplings, the higher length-classes were mostly represented by females while males showed predominance in the smaller classes, which is probably related to specific genetic traits (Fletcher and Wootton, 1995; Kraak and Baker, 1998), since there is no information suggesting that females live longer than males and that they could attain larger dimensions. Two juvenile individuals were also caught, with total lengths of $17 \mathrm{~mm}$ and $24 \mathrm{~mm}$. Considering that the juveniles of $G$. aculeatus can attain a total length of $17 \mathrm{~mm}$ in the first month (Allen and Wooton, 1982), and assuming that the same occurs in the study area, there is the possibility that in the Almansor River, the breeding season of this species did not start in April but nearly a month earlier. In the threespine stickleback length-frequency distribution in April 2006 samplings, it was possible to identify three peaks that probably correspond to the modal classes of length frequency distribution associated with each age-class, which is in agreement with several studies of age and growth for this species, that generally has a maximum longevity of three years, exhibiting mean total lengths for each ageclass, similar to the ones observed in this study (Jones and Hynes, 1950; Rubidge, 2000). According to these authors, a 1-year old individual may exhibit a total length between $35 \mathrm{~mm}$ and $40 \mathrm{~mm}$, while a 2-year old individual normally has a maximum total length of nearly $45 \mathrm{~mm}$. Threespine sticklebacks aged 3 years may attain a total length comprised between $50 \mathrm{~mm}$ and $55 \mathrm{~mm}$. Based only in the length frequency distribution, the same situation seems to occur with this $G$. aculeatus southern European population, in the Almansor River. However, our results are different from the ones described for other Mediterranean areas (Crivelli \& Britton, 1987; Poizart et $a l ., 2005)$ where this species generally presents a strictly annual life cycle with adults dying shortly after the first breeding season. This fact is commonly seen as an adaptation to a Mediterraneantype climate (high summer temperatures, seasonality of water bodies) and thus, a similar situation was expected to happen in our study. Becau- se the age of the sampled sticklebacks was not confirmed by otholits analysis, it remains uncertain if the studied population really exhibited the three common age classes of this species, being an exception to other Mediterranean populations, or if the observed differences in size were only related to individual growth rates of the same age group. To shed light on the results obtained by the length distribution analysis, a new and more comprehensive study about the genetics and age and growth of the studied population is important in order to attain a better management of the species in this region.

During the breeding season, the variables related to male abundance in the Almansor River were the fish species-richness, the aquatic vegetation cover and the abundance of potential predators. The positive relation obtained for "species-richness" may indicate a search by the male, during this season, of sites with higher ecological quality and capable of sustain a more complex community. The vegetation cover was also positively related to male abundance. Being a territorial species, especially during the breeding season, these individuals usually prefer more vegetated sites that could grant them and their nests some protection, not only against predators but also against other sticklebacks. These results corroborate several studies (Cleveland, 1994; Peultkuri et al., 1995; Almaça, 1996; Rodewald and Foster, 1998; Doadrio, 2001; Candolin and Voigt, 1998, 2003), in which the great preference of this species for well vegetated sites is also noted. A negative relation was observed between male distribution and the abundance of potential predators indicating that males of this species were more abundant at sites with fewer potential predators. The presence of threespine stickleback predators is considered by some authors as an influence on the choice of the nest site made by the male (Rodewald and Foster, 1998; Candolin and Voigt, 2003). Corroborating this result, in a study developed by Garcia-Berthou and Moreno-Amich (2000), the introduction of exotic species, especially predators such as Micropterus salmoides (Lacépède, 1802) (largemouth bass) or the pumpkinseed sunfish, is described as the main cause for the local extinction of threespine stickleback in an Iberian lake. 
Male abundance is the main variable influencing female distribution. During the breeding season, threespine stickleback females occur preferentially at sites where male abundance is higher. This result corroborates what is described by other authors (Sterba, 1973; Doadrio, 2001) indicating that males choose the nest site to where the females are subsequently attracted and deposit their eggs. When the effect of male abundance was removed from the statistical analysis, the results show that the females' site choice is practically identical to the results obtained for males. During breeding season, threespine stickleback female abundance is also positively related to fish species-richness and aquatic vegetation cover. This last variable is particularly important to females, which are less capable of escaping from predators during breeding season due to their swollen abdomen (Candolin and Voigt, 1998; Rodewald and Foster, 1998).

The variable "thermal amplitude" did not enter into any of the statistical models but still seems to be related to threespine stickleback distribution in the Almansor River. This variable shows a sharp decrease between sites A7 and A8, possibly due to the existence of a denser riparian habitat in the upstream sampled sites. Curiously, with the exception of site A6, the great majority of individuals were caught upstream from site A7, implying that threespine sticklebacks shows a preference, specially during breeding season, for more sheltered sites with higher protection against temperature variations (Candolin and Voigt, 2003).

Besides the results obtained in this study, there are other environmental parameters considered by some authors as having influence on this species' distribution that did not enter in any of the statistical models (Mori, 1994; Prenda et al., 1997, Rodewald and Foster, 1998; Candolin and Voigt, 2003; Copp and Kovac, 2003; Webster and Hart, 2004). The relative homogeneity of variables such as depth or sediment composition in this river may be one of the causes for the lack of a significant relation with this species abundance. The current velocity is also described as being negatively related to threespine stickleback distribution during the breeding season. However, in the majority of the sampled sites almost all sti- cklebacks were caught near the margin were the current velocity was slow or negligible, diminishing this variable effect, which is in accordance with the results described by Mori (1994).

In conclusion, this study shows that, during the breeding season, male threespine sticklebacks in this river build their nests in well vegetated and structurally complex sites, with fewer potential predators and more protected from environmental fluctuations and anthropogenic pressures. Females' distribution during this period is heavily influenced by male distribution. Due to the probable absence of an anadromous form and the extremely localised distribution in the upstream reaches of the river, this population could well be suffering an accentuated decline. In these Mediterranean type rivers, and due to their intermittent flow regime, this species suffers some constraints with a great part of the recruitment confined to isolated stream bed pools, dying when the environmental conditions start to decline, as it was shown in this study. Being a species with a conservation status of Endangered (EN) in Portugal (Rogado et al., 2005) and considering the lack of attention given to the fish populations of this type of rivers, this study allows future management proposals for the protection of this species, based on the knowledge of the preferential sites for its reproduction in a intermittent stream like the Almansor River.

\section{ACKNOWLEDGEMENTS}

The authors wish to thank Silvia Pedro, João Ferreira, Inês Póvoa, Sara Pinela, and Cláudia Suissas for their precious assistance during field sampling. We are also grateful to Bernardo Quintella for the support, suggestions, and corrections proposed during this study.

\section{REFERENCES}

ALLEN, J. R. M. \& R. J. WOOTTON. 1982. Age, growth and rate of food consumption in an upland population of the threespined stickleback, Gasterosteus aculeatus L.. J. Fish Biol., 21: 95-105.

ALMAÇA, C. 1996. Peixes dos rios de Portugal. 
Edições INAPA. 129 pp.

ALMEIDA, P. R. \& B. R. QUINTELLA. 2002. Larval habitat of the sea lamprey (Petromyzon marinus L.) in the River Mondego (Portugal). In: Freshwater fish conservation: options for the future. $\mathrm{M}$. J. Collares-Pereira, M. M. Coelho, I. G. Cowx (Eds.): 121-130. Fishing News Books, Blackwell Science. Oxford,

ALMEIDA, P. R., F. MOREIRA, J. L. COSTA, C. A. ASSIS \& M. J. COSTA. 1993. The feeding strategies of Liza ramada (Risso, 1826) in fresh and brackish water in the River Tagus, Portugal. J. Fish Biol., 42: 95-107.

BERNA, T. M. 2001. Freshwater Fish Distribution. United Kigdom: Academic Press. 604 pp.

CANDOLIN, U. \& H. R. VOIGT. 1998. Predatorinduced nest site preference: safe nests allow courtship in sticklebacks. Anim. Behav., 56: 1205-1211.

CANDOLIN, U. \& H. R. VOIGT. 2003. Do changes in risk-taking affect shifts of sticklebacks? Behav. Ecol. and Sociobiol., 55: 42-49.

CLEVELAND, A. 1994. Nest site habitat preference and competition in Gasterosteus aculeatus and Gasterosteus wheatlandi. Copeia, 3: 698-704.

COPP, G. H. \& V. KOVÁC. 2003. Sympatry between threespine Gasterosteus aculeatus and ninespine Pungitius pungitius sticklebacks in English lowland streams. Annu. Zool. Fenn., 40: 341-355.

CRIVELLI, A. J. \& R. H. BRITTON. 1987. Life history adaptations of Gasterosteus aculeatus in a Mediterranean wetland. Environ. Biol. Fish., 18: 109-125.

DOADRIO, I. 2001. Atlas y libro rojo de los peces continentales de España. Dirección General de Conservación de la Naturaleza. Museo Nacional de Ciencias Naturales (CSIC). Madrid. 364 pp.

ELLIOTT, J. M. 2000. Pools as refugia for brown trout during two summer droughts: trout responses to thermal and oxygen stress. J. Fish Biol., 56: 938948.

FERNÁNDEZ, C., M. HERMIDA, R. AMARO \& E. SAN MIGUEL. 2000. Lateral plate variation in Galician stickleback populations in the rivers Miño and Lima, NW Spain. Behaviour, 137: 965-979.

FLETCHER, D. A. \& R. J. WOOTTON. 1995. Hierarchical response to differences in ration size in the reproductive performance of female threespined sticklebacks. J. Fish Biol., 46: 657-668.

FOSTER, S. A., J. A. BAKER \& M. A. BELL. 2003. The case for conserving three spine stickleba- ck populations-Protecting an adaptative radiation. Fisheries, 28: 10-18.

GARCIA-BERTHOU, E. \& R. MORENO-AMICH. 2000. Introduction of exotic fish into a Mediterranean lake over a 90-year period. Arch. Hydrobiol., 149(2): 271-284.

GASITH, A. \& V. H. RESH. 1999. Streams in mediterranean climate regions: abiotic influences and biotic responses to predictable seasonal events. Annu. Rev. Ecol. Syst., 31: 51-58.

HAGEN, D. W. 1967. Isolating mechanisms in threespine sticklebacks (Gasterosteus). J. Fish. Res. Board Can., 24: 1637-92.

HERMIDA, M., J. C. FERNÁNDEZ, R. AMARO \& E. SAN MIGUEL. 2005. Morphometric and meristic variation in Galician threespine stickleback population, northwest Spain. Environ. Biol. Fish., 73: 189-200.

ILHÉU, M. A. P. 2004. Padrões de uso de habitat da ictiofauna em rios de tipo mediterrânico. Tese para a obtenção do grau de doutor em Ciências do Ambiente. Universidade de Évora. 274 pp.

INAG 1999. Síntese da análise e diagnóstico da situação actual. In: Plano da Bacia Hidrográfica do Rio Tejo Vol. III-Análise. 101 pp.

JONES, J. W. \& H. B. N. HYNES. 1950. The age and growth of Gasterosteus aculeatus, Pygosteus pungitius and Spinachia vulgaris. J. Anim. Ecol., 19: 59-73.

KOTTELAT, M. \& J. FREYHOF. 2007. Handbook of European Freshwater Fishes. Kottelat, Cornol, Switzerland and Freyhof. Berlin, Germany. $646 \mathrm{pp}$.

KRAAK, S. B. M. \& T. C. M. BAKER. 1998. Mutual mate choice in sticklebacks: attractive males choose big females, which lay big eggs. Anim. Behav., 56: 859-866.

LEWIS, D. B., M. WALKEY \& H. J. G. DARTNALL. 1972. Some effects of low oxygen tensions on the distribution of the three-spined stickleback Gasterosteus aculeatus L. and the nine-spined stickleback Pungitius pungitius (L.). J. Fish Biol., 4: 103-108.

LIYTHGOE, J. \& G. LIYTHGOE. 1971. Fishes of the sea: The coastal waters of the British Isles, Northern Europe and the Mediterranean. Eds. Blandford, London. $320 \mathrm{pp}$.

LOBÓN-CERVIA, J., T. PENZACK \& A. de SOSTOA. 1988. Morphological variability and distribution of stickleback (Gasterosteus aculeatus L.) in Spain. Cybium, 12: 219-227. 
MAGOULICK, D. D. 2000. Spatial and temporal variation in fish assemblages of drying stream pools: The role of abiotic and biotic factors. Aquat. Ecol., 34: 29-41.

MATTERN, M. Y. 2004. Molecular phylogeny of the Gasterosteidae: the importance of using multiple genes. Mol. Phylogen. Evol., 30: 366-377.

MATTHEWS, W. J. 1998. Patterns in Freshwater Fish Ecology. Chapman \& Hall, New York. $755 \mathrm{pp}$.

MORI, S. 1994. Nest site choice by the three-spined stickleback, Gasterosteus aculeatus (form leiurus), in spring-fed waters. J. Fish Biol., 45: 279-289.

MOYLE, P. B. \& B. VONDRACEK. 1985. Persistence and structure of the fish assemblage in a small California stream. Ecology., 66: 1-13.

MUNDAHL, N. D. 1990. Heat death of fish in shrinking stream pools. Am. Midl. Nat., 123: 40-46.

OSTRAND, K. G. \& G. R. WILDE. 2004. Changes in prairie stream fish assemblages restricted to isolated streambed pools. Trans. Am. Fish. Soc., 133: 1329-1338.

PÁLL, M. K., A. HELLQVIST, M. SCHMITZ, E. OLSSON, I. MAYER \& B. BORG. 2005. Changes in reproductive physiology and behaviour over the nesting cycle in male three spined sticklebacks. J. Fish Biol., 66: 1400-1410.

PEULTKURI, N., E. RANTA, S. JUVOREN \& K. LINDSTRÖM. 1995. Schooling affects growth in the three-spined sticklebacks, Gasterosteus aculeatus. J. Fish Biol., 46: 221-226.

POIZART, G., E. ROSECCHI \& A. J. CRIVELLI. 2005. Life-history variation within a threespined stickleback population in the Camargue. J. Fish Biol., 60(5): 1296-1307.

PRENDA, J., P. D. ARMITAGE \& A. GRAYSTON. 1997. Habitat use by fish assemblage of two chalk streams. J. Fish Biol., 51: 64-79.
RODEWALD, A. D. \& S. A. FOSTER. 1998. Effects of gravidity on habitat use and anti-predatory behaviour in three-spined sticklebacks. J. Fish Biol., 52: 973-984.

ROGADO, L. (Coord.), P. ALEXANDRINO, P. R. ALMEIDA, J. ALVES, J. BOCHECHAS, R. CORTES, I. DOMINGOS, F. FILIPE, J. MADEIRA e F. MAGALHÃES. 2005. Fichas de caracterização-Peixes. In: Livro Vermelho dos Vertebrados de Portugal. Cabral, M. J. et al. (eds.): 63114. Instituto da Conservação da Natureza. Lisboa.

ROUX, R. M. 1964. Les sediments de l'étange de Reine. Recueils des Travaux de la Station Marine d'Endoume, 35: 257-285.

RUBIDGE, E. 2000. Variability within the Gasterosteus species complex in Coastal B. C. Royal British Columbia Museum. Belleville Street, Victoria, B. C. $11 \mathrm{pp}$.

RUNDLE, H. D., L. NAGEL, J. W. BOUGHMAN \& D. SCHLUTER. 2000. Natural selection and parallel speciation in sympatric sticklebacks. Science, 287: 306-308.

SCHWARTZ, S. S. \& D. G. JENKINS. 2000. Temporary aquatic habitats: constraints and opportunities. Aquat. Ecol., 34: 3-8.

SNYDER, R. J. 1991. Migration and life histories of the threespine stickleback: evidence for adaptive variation in growth rate between populations. Environ. Biol. Fishes, 31: 381-388.

SONCINI, R. \& M. L. GLASS. 1997. The effects of temperature and hyperoxia on arterial $\mathrm{PO}_{2}$ and acid-base status in Piaractus mesopotamicus. J. Fish Biol., 51: 225-233.

STERBA, G. 1973. Freshwater fishes of the world. Vol. 2. T.F.H. Publications. 877 pp.

WEBSTER, M. M. \& P.J. B. HART. 2004. Substrate discrimination and preference in foraging fish. Anim. Behav., 68: 1071-1077. 